\title{
Article \\ Experimental Study on Physical Mechanical Properties and Microstructure of Diatomite Soil in Zhejiang Province, China
}

\author{
Lei Gao ${ }^{1, *}$, Yi Luo ${ }^{1}$, Yingeng Kang ${ }^{2}$, Mingjun Gao ${ }^{1}$ and Omar Abdulhafidh ${ }^{1}$ \\ 1 Key Laboratory of Ministry of Education for Geomechanics and Embankment Engineering, Hohai University, \\ Nanjing 210024, China; loy@hhu.edu.cn (Y.L.); Mjgao2222@sina.com (M.G.); Omarabdo@hhu.edu.cn (O.A.) \\ 2 China Railway Design Group Corporation, Tianjin 300142, China; kangyingeng@163.com \\ * Correspondence: gaoleihhu@hhu.edu.cn; Tel.: +86-025-83787687
}

check for

updates

Citation: Gao, L.; Luo, Y.; Kang, Y.; Gao, M.; Abdulhafidh, O. Experimental Study on Physical Mechanical Properties and Microstructure of Diatomite Soil in Zhejiang Province, China. Appl. Sci. 2022, 12, 387. https://doi.org/ 10.3390/app12010387

Academic Editor: Claudio De Pasquale

Received: 11 November 2021 Accepted: 13 December 2021 Published: 31 December 2021

Publisher's Note: MDPI stays neutral with regard to jurisdictional claims in published maps and institutional affiliations.

Copyright: (c) 2021 by the authors. Licensee MDPI, Basel, Switzerland. This article is an open access article distributed under the terms and conditions of the Creative Commons Attribution (CC BY) license (https:/ / creativecommons.org/licenses/by/ $4.0 /)$.

\begin{abstract}
Diatomite soil is a kind of bio-siliceous soil with complex composition and special structure, the physical and mechanical properties of diatomite soil are very important for the engineering project. In this paper, the physical properties, mechanical properties, and microstructure of diatomite soil in Zhejiang Province are studied by geotechnical tests and microscopic tests from the macroscopic and microscopic perspective. The results show that: (1) The diatomite soil has special properties different from other soils, including small particle size, low specific gravity value, high liquid-plastic limit, and low compressibility, and the strength indexes $c$ and $\varphi$ of diatomite soil will decrease with an increase in soil water content; (2) in the triaxial test, when the dry density of diatomite soil increases from $1.30 \mathrm{~g} / \mathrm{cm}^{3}$ to $1.50 \mathrm{~g} / \mathrm{cm}^{3}$, the effective internal friction angle of diatomite soil increases from $5.6^{\circ}$ to $14.5^{\circ}$ and the effective cohesion increases from $30.9 \mathrm{kPa}$ to $49.6 \mathrm{kPa}$. The stress-strain curve of diatomite soil changes from weak softening type to weak hardening type when the confining pressure is above $200 \mathrm{kPa}$; (3) the diatomite soil has high porosity due to its unique microstructure; it is rich in aluminum oxides and minerals, which will greatly reduce the engineering performance of diatomite soil.
\end{abstract}

Keywords: diatomite soil; physical properties; mechanical properties; microstructure; influence mechanism

\section{Introduction}

Diatomite soil is a kind of porous siliceous soil, which is formed by the accumulation of diatoms and other plant remains. Diatomite soil has different colors according to its mineral content, usually light or gray-black color. There are abundant diatomite soil resources in the world, it is estimated that the geological reserves of diatomite soil in the world are at least two billion tons. It is mainly distributed in China, the United States, Denmark, France, and other places [1,2].

Diatomite soil has special structural and chemical stability, which is characterized by soft texture, high adsorption, high porosity, and low density [3]. At present, it is often used as an adsorption material in the chemical industry [4-6]. The main component of diatomite soil is $\mathrm{SiO}_{2}$, and it contains more clay minerals, detritus, and organic matter [7-9]. Considering the influence of the external environment and the difference in material composition, the change in diatomite soil microstructure will directly affect its macro and micromechanical properties [10-12]. Relevant tests show that different calcination temperatures can affect the microstructure of diatomite soil $[13,14]$. The $\mathrm{SiO}_{2}$ content of diatomite soil is the standard to judge the quality of diatomite soil, whether in the development and utilization of non-metallic materials or in geotechnical engineering [15]. The diatomite soil which is used as filling soil in Southern California, USA, has a density of $1.0-1.2 \mathrm{~g} / \mathrm{cm}^{3}$ and a water content of $38-53 \%$ and belongs to soil with low dry density and high natural water content [16-18]. For natural diatomite soil in Japan, research shows that the natural water content ratio and $\mathrm{SiO}_{2}$ content of diatomite soil are very 
high [19]. Diatomite soil also has low shear strength, complex composition, different degrees of expansibility, and usually contains clay minerals, carbon, iron, carbonate, and other minerals [20-25]. Moreover, it is easy to soften when encountering water and its engineering properties are poor [26-32].

In recent years, infrastructure construction is increasing. From ports in Africa to the Hangzhou Shaoxing high-speed railway in China, a large number of roads, ports, and highspeed railways are being built in diatomite soil areas. Due to the lack of understanding of the characteristics of diatomite soil, many engineering problems are brought about. Through the analysis of engineering data, it is found that diatomite soil has different colors-usually white, yellow, black, and other colors. Currently, there are minimal studies on physical and mechanical strength changes in diatomite soil. In order to serve the construction needs of the national high-speed railway, it is necessary to study and analyze the diatomite soil from a macroscopic and microscopic perspective.

In this paper, diatomite soil was taken from the Hangzhou-Taizhou high-speed railway project in Zhejiang Province, China, since this new high-speed railway project is built in a diatomite soil area. The properties of diatomite soil are very important. A series of basic tests such as consolidation tests, direct shear tests, and triaxial shear tests were carried out. Combined with SEM and XRD tests, the mechanisms of deformation and mechanical properties change in diatomite soil are analyzed from macroscopic and microscopic perspectives.

\section{Materials and Methods}

\subsection{Materials}

Diatomite soil was from Shaoxing City, Zhejiang Province, China. The soil layers are the silty clay layer, diatomite soil layer, and diatomite-containing sandstone layer from top to bottom. The appearance of the diatomite soil selected is white in the air-dried state, the depth of the soil layer is no more than $40 \mathrm{~m}$ (sampling depth is within five meters), and the weathering is strong. According to the test results of the natural soil water content, the natural water content of diatomite soil is higher than $40 \%$. The diatomite soil in the natural state is shown in Figure 1.

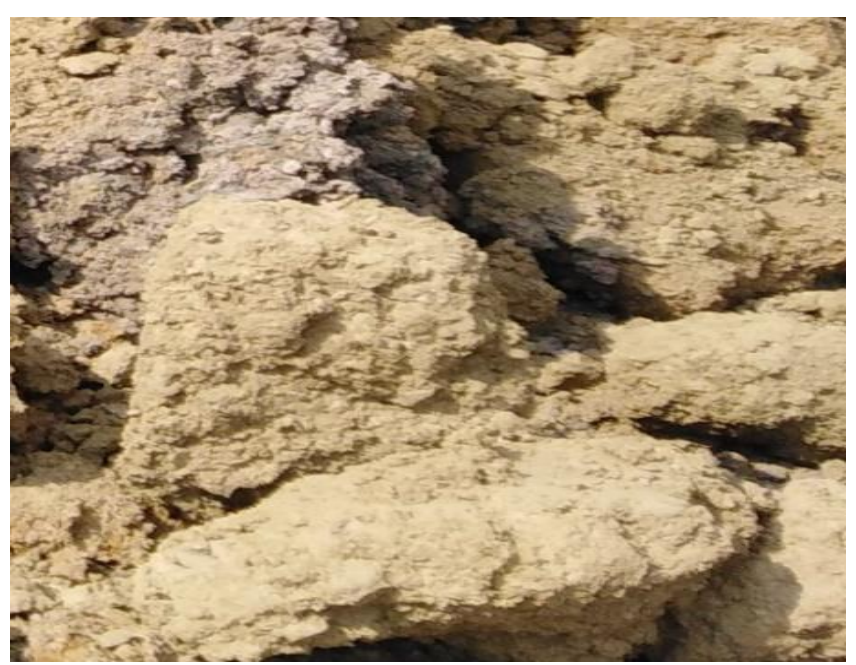

Figure 1. Diatomite soil.

\subsection{Methods}

Diatomite soil from the site was air-dried, crushed, and remolded; the remolded soil was tested. The basic physical property tests include the particle analysis test, the specific gravity test, and the liquid-plastic limit test. The mechanical characteristic tests include the consolidation test, the direct shear test, and the triaxial test. 
The one-dimensional consolidation test is mainly used to determine the consolidation coefficient and compression index of diatomite soil. Considering the high water content of diatomite soil on site, the diatomite soil samples were prepared with $40 \%$ water content and the dry density of samples was controlled with $1.10 \mathrm{~g} / \mathrm{cm}^{3}$ in this test. The maximum vertical pressure of the consolidation test was controlled to not exceed $1600 \mathrm{kPa}$.

The strain-controlled direct shear apparatus was used in the direct shear test. In order to simulate a situation in which the construction speed is fast and the soil is sheared before consolidation, this test adopts the fast shear method. During the test, the water content was taken as the control variable of soil samples, and soil samples with $20 \%$ water content and $40 \%$ water content were prepared, respectively. The dry density of the soil sample is controlled as $1.10 \mathrm{~g} / \mathrm{cm}^{3}$.

In the triaxial test, the LSY30-1 stress-strain control triaxial apparatus was used. The soil sample had a diameter of $39.1 \mathrm{~mm}$ and a height of $80 \mathrm{~mm}$. Considering that the diatomite soil mainly bears a fast load, it is difficult to drain water in the shear process, and the consolidation undrained method was used in this test. Because the saturated samples cannot be distinguished by water content, the dry density was used to control the conditions of different samples. Combined with the state conditions of natural diatomite soil, the test dry densities of soil samples are $1.30 \mathrm{~g} / \mathrm{cm}^{3}, 1.40 \mathrm{~g} / \mathrm{cm}^{3}$, and $1.50 \mathrm{~g} / \mathrm{cm}^{3}$; the sample density was controlled with $1.82 \mathrm{~g} / \mathrm{cm}^{3}$ before saturation. All tests were followed by geotechnical test procedures $[33,34]$.

\section{Results}

\subsection{Basic Physical Property Tests}

The particle size distribution curve of diatomite soil is shown in Figure 2. From the results of the particle size test, the particle size of diatomite soil is relatively small, more than $50 \%$ of soil particles have a particle size below $0.002 \mathrm{~mm}$.

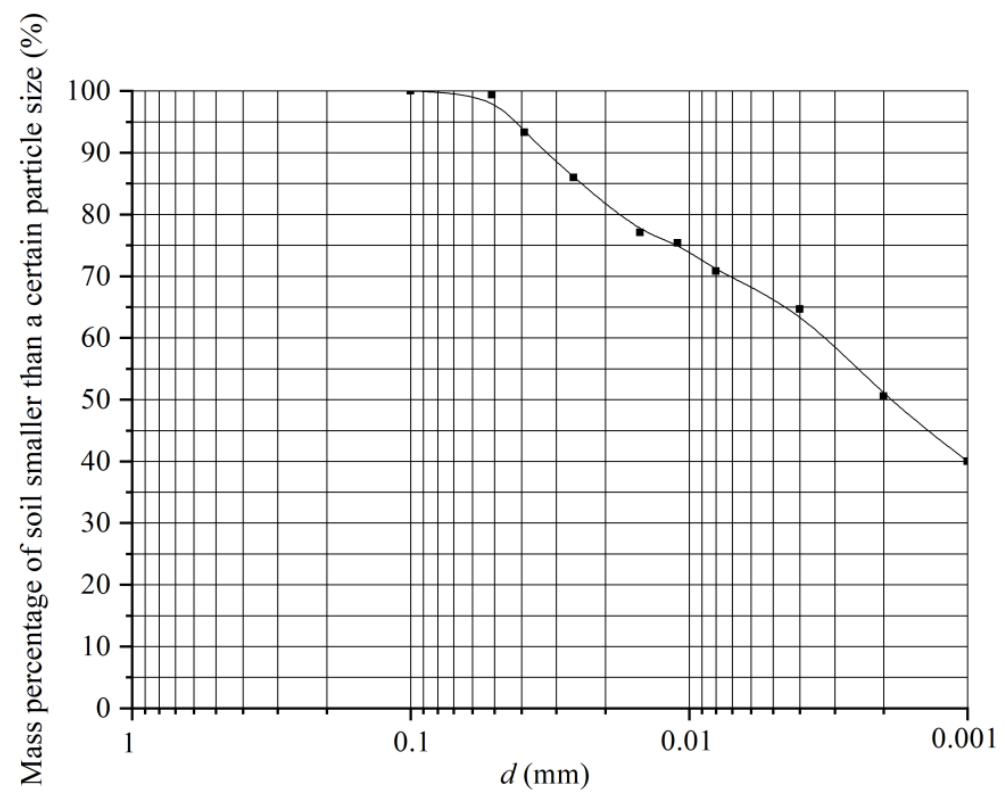

Figure 2. Particle size distribution curve of diatomite soil.

The physical indicators of diatomite soil are shown in Table 1:

Table 1. Physical indicators of diatomite soil.

\begin{tabular}{ccccc}
\hline$G_{s}$ & $\omega_{P} / \%$ & $\omega_{L} / \%$ & $I_{P}$ & $I_{L}$ \\
\hline 2.47 & 36.69 & 94.91 & 59 & 0.07 \\
\hline
\end{tabular}

$\overline{G_{S}}=$ specific gravity; $\omega_{P}=$ plastic limit; $\omega_{L}=$ liquid limit; $I_{P}=$ plasticity index; $I_{L}=$ liquidity index. 
The results of the specific gravity test show that the average value of specific gravity of diatomite soil used in this test is 2.47. The results of the liquid-plastic limit test show that the liquid limit of diatomite soil is $94.91 \%$, the plastic limit is $36.69 \%$, the plasticity index is 59 , and the liquidity index is 0.07 .

\subsection{Mechanical Strength Characteristic Tests}

\subsubsection{Consolidation Test}

The results of the consolidation test of diatomite soil are shown in Table 2.

Table 2. Results of consolidation test.

\begin{tabular}{ccccc}
\hline $\boldsymbol{a}_{v}\left(\mathrm{MPa}^{-1}\right)$ & $\left.\boldsymbol{E}_{\boldsymbol{s}} \mathbf{( M P a}\right)$ & $\boldsymbol{C}_{\boldsymbol{c}}$ & $\boldsymbol{C}_{\boldsymbol{s}}$ & $\boldsymbol{C}_{\boldsymbol{v}}\left(\mathrm{cm}^{2} / \mathbf{s}\right)$ \\
\hline $1.03 \sim 1.01$ & $2.272 \sim 2.277$ & $0.342 \sim 0.336$ & $0.043 \sim 0.060$ & $(2.58 \sim 2.87) \times 10^{-5}$ \\
\hline $\boldsymbol{a}_{v}=$ compression coefficient; $E_{s}=$ compressive modulus; & $C_{c}=$ compression index; $C_{s}=$ rebound index; \\
$C_{v}=$ consolidation coefficient. &
\end{tabular}

It can be seen from the table that the compression coefficient $a_{v}$ of diatomite soil reaches more than $1 \mathrm{MPa}^{-1}$. The compressive modulus is $2.272 \sim 2.277 \mathrm{MPa}$. The compression index is between 0.342 and 0.336 , while the rebound index ranges from 0.043 to 0.060 . The consolidation coefficient of diatomite soil is relatively small.

\subsubsection{Direct Shear Test}

According to the relationship between the shear stress and shear displacement, the strength indexes $c$ and $\varphi$ of diatomite soil with different water content are obtained. When the water content of the sample is $20 \%$, the shear strength indexes of the three groups of parallel test soil samples are $50.2 \mathrm{kPa}$ and $8.0^{\circ}, 48.7 \mathrm{kPa}$ and $8.5^{\circ}$, and $47.8 \mathrm{kPa}$ and $8.6^{\circ}$, respectively; when the water content of the sample is $40 \%$, the shear strength indexes of the three groups of parallel test soil samples are $26.5 \mathrm{kPa}$ and $5.6^{\circ}, 27.1 \mathrm{kPa}$ and $5.5^{\circ}$, and $27.4 \mathrm{kPa}$ and $5.5^{\circ}$, respectively. It can be seen that its overall internal friction angle is small.

\subsubsection{Triaxial Test}

According to the results of total stress and effective stress of diatomite soil under different dry densities, the relationship curve between effective average stress $p^{\prime}$ and deviatoric stress $q^{\prime}$ is shown in Figure 3.

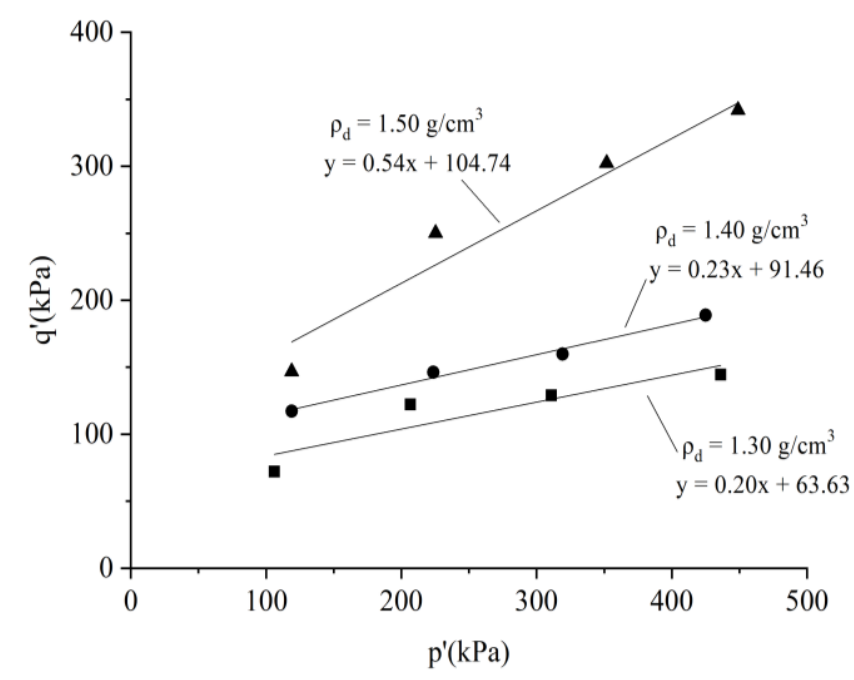

Figure 3. Relationship curve of $p^{\prime}$ and $q^{\prime}$.

It should be noted that in this triaxial test, the normal consolidated saturated clay sample is used for the consolidated undrained (CU) test, and the theoretical cohesive force 
of clay is 0 . In this test, the samples with dry density higher than that of natural diatomite soil are used for the test. During the pre-consolidation process, the set consolidation stress is directly increased to the required value of the test, making the sample in the over consolidation state, Moreover, the soil sample in this test had a large cohesion.

The triaxial test results of diatomite soil with different dry densities show that the effective internal friction angle of diatomite soil is $5.6^{\circ}$ and the effective cohesion is $30.9 \mathrm{kPa}$ when the dry density is $1.30 \mathrm{~g} / \mathrm{cm}^{3}$. Meanwhile, the effective internal friction angle of diatomite soil is $6.4^{\circ}$ and the effective cohesion is $44.3 \mathrm{kPa}$ when the dry density is $1.40 \mathrm{~g} / \mathrm{cm}^{3}$. The effective internal friction angle of diatomite soil is $14.5^{\circ}$ and the effective cohesion reaches $49.6 \mathrm{kPa}$ when the dry density is $1.50 \mathrm{~g} / \mathrm{cm}^{3}$.

\section{Discussion}

\subsection{Microstructure and Composition of Diatomite Soil}

The direct shear test and triaxial test results show that the diatomite soil exhibits different mechanical properties under different water content, the mechanical strength index of diatomite soil decreases with the increase in water content in diatomite soil. In this paper, the microstructure and element mineral composition of diatomite soil are studied by scanning electron microscope (SEM) and XRD experiments.

Figure 4 shows the results of SEM, Figure $4 \mathrm{a}$ is 5000 times and Figure $4 \mathrm{~b}$ is 10,000 times magnification. The SEM results of diatomite soil show that the diatomite soil contains many orderly arranged pore structures. The clay minerals in the whole diatomite soil show the structure of a parallel sheet and fold sheet. The aggregation among the grain groups is mainly in the form of a stacked polymerization arrangement. The overall structure of diatomite soil is presented as the dispersed structure. The clay particles and diatom debris grains are arranged nearly in parallel, and the contact form is surface-to-surface. This unique microstructure makes the diatomaceous soil relatively high in porosity, which shows a property of being easily soaked in water.

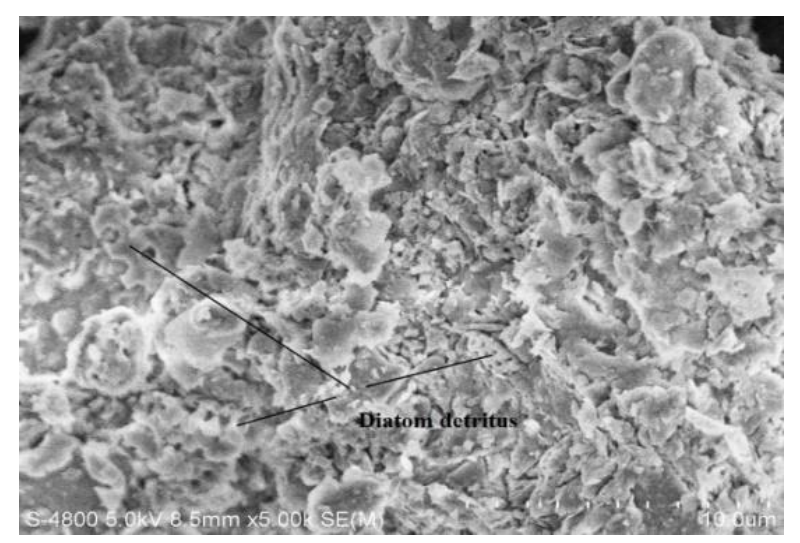

(a)

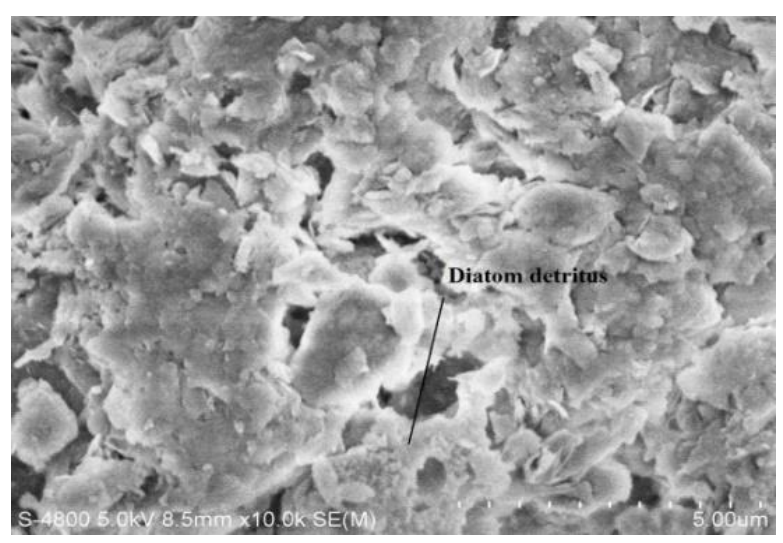

(b)

Figure 4. SEM results of diatomite soil. (a) 5000 times; (b) 10,000 times.

Through the X-ray diffraction test, the elemental composition of the diatomite soil is analyzed. Figure 5 shows the XRD composition results. The XRD results show that there are many chemical elements in diatomite soil, including $\mathrm{Si}, \mathrm{K}, \mathrm{Al}, \mathrm{H}, \mathrm{O}$, etc. The diatomite soil has different physical and mechanical properties because of the different ion content, these elements exist in the form of oxides in diatomite soil. The results show that diatomite soil has higher aluminum content. Aluminum is usually combined with other elements such as silicon and oxygen to form a variety of oxides and minerals. It is mainly composed of diatom remains (about 15-20\%) and clay minerals (about 80-85\%), and the content of diatom debris is slightly higher. The results show that the content of kaolinite and mica in diatomite soil is high, which is the main reason for its poor engineering properties. 


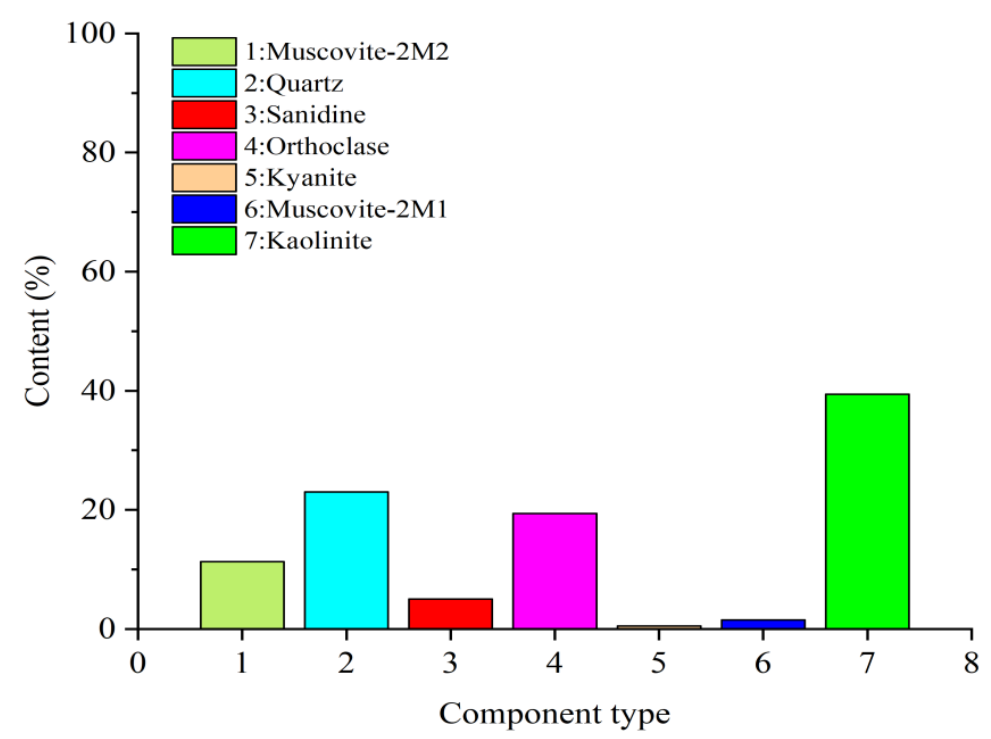

Figure 5. Composition results of XRD.

There are many pores in diatomite soil, when the soil is relatively dry and the pores are large, the suction between particles in diatomite soil is small, they are separated from each other. The contact between particles is surface-to-surface contact. The structural force between layers is provided by the indirect contact surface of particles, and the contact area is large. The soil structure is stable, and the strength of diatomite soil is high. When the pores in the soil decrease and the pores are gradually filled with water, the suction between the molecules increases and the fine particles in the soil adhere to each other under suction, forming small aggregates. As a result, the contact area between soil particles gradually tends to point-to-point form. Because the content of kaolinite, mica, debris, and other minerals in diatomite soil is higher when water enters the soil, the soil will show certain volume expansion and softening characteristics, and its mechanical strength characteristics will decline.

\subsection{Basic Physical and Deformation Characteristics of Diatomite Soil}

Through a series of indoor physical properties tests, the results show that the particle size of diatomite soil is small. The specific gravity of diatomite soil particles is low. Taking into account the special mineral element composition of diatomite soil, a greater minerals content may be the reason for the low specific gravity of diatomite soil particles. Its liquidplastic limit is high and the clay content of diatomite soil is higher, and its liquidity index $I_{L}=0.07 \leq 1.0$. It can be concluded that this kind of diatomite soil is in a plastic state. According to the code for the design of building foundations [32], this diatomite soil is in a hard plastic state. It can be seen from the consolidation test results that the compression coefficient $a_{v}$ of the samples is large, this diatomite soil belongs to high compressibility soil. The compression modulus of diatomite soil is low, which shows that this kind of sample has a weak ability to resist compression deformation under the condition of unidirectional compression. At the same time, the compression index of diatomite soil shows that this kind of diatomite soil has large compressibility; the rebound index indicates that the rebound and recompression deformation ability of diatomite soil is weak. The consolidation coefficient of diatomite soil is small, which indicates that the drainage speed of diatomite soil is low in the consolidation process. The diatomite soil is rich in aluminosilicate, it contains more kaolinite, mica, and other minerals in mineral composition; furthermore, it will show strong water absorption and certain volume expansion. Considering the high natural water content of diatomite soil, the entry of water molecules breaks the overlapping cell structure composed of silicon, aluminum, and oxygen, which leads to a softening effect and volume expansion of diatomite soil. 


\subsection{Mechanical Properties of Diatomite Soil in Direct Shear Test}

Through the direct shear test, 24 groups of diatomite soil samples with different water contents are used. It is found that the mechanical strength index of diatomite soil has obvious characteristics with $20 \%$ water content and $40 \%$ water content. Comparing the strength index of diatomite soil with $20 \%$ water content and that of diatomite soil with $40 \%$ water content, it can be seen that when the water content rises from $20 \%$ to $40 \%$, the cohesive force $C$ of diatomite soil greatly decreases, the cohesive force $C$ of diatomite soil with $20 \%$ water content is about twice than that of diatomite soil with $40 \%$ water content, the internal friction angle of diatomite soil with $40 \%$ water content diatomite soil is $3^{\circ}$ lower than that of diatomite soil with $20 \%$ water content. The test shows that the water content in diatomite soil will affect its shear strength—it will change the cohesion and internal friction angle of the soil.

The undisturbed diatomite soil has a strong structure, it shows better mechanical strength properties. The diatomite soil has special element mineral composition, strong water absorption, and softening characteristics; the original stable silicon aluminum oxide laminated crystal cell structure will be affected by the water molecules; it will show the phenomenon of softening and volume expansion on the macro level; its mechanical strength characteristics will be affected. At the same time, water can reduce the cohesion of soil by influencing the bite force between particles and the friction force generated by the particles. It has a tremendously adverse effect on the stress of diatomite soil due to its expansion characteristics when encountering water.

\subsection{Mechanical Properties of Diatomite Soil in Triaxial Test}

In the triaxial test, the sample is saturated. This test controls the water content of the sample by controlling the different dry densities under the same density. A change in the mechanical properties of the sample was obtained. The results show that the shear strength of soil samples will be different under different dry densities. During the whole failure process of the sample, the volume of diatomite soil is easy to expand because of its water swelling property. It can change the stress of the diatomite soil in the shear process and affect its mechanical strength characteristics. The failure form of the soil sample is shown in Figure 6, in which it can be seen when the shear failure displacement occurs.

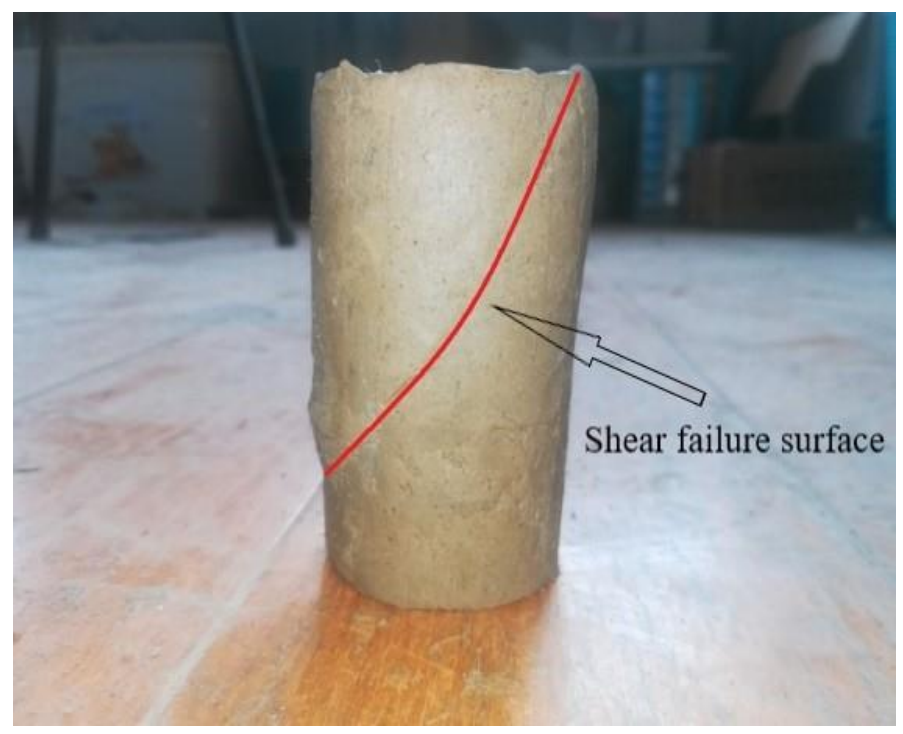

Figure 6. Failure of diatomite soil sample.

Comparing the stress-strain curves of diatomite soil under three kinds of dry densities, it is found that when the dry density of diatomite soil increases from $1.30 \mathrm{~g} / \mathrm{cm}^{3}$ to $1.50 \mathrm{~g} / \mathrm{cm}^{3}$, the stress-strain curve of diatomite soil changes from a weak softening type 
to a weak hardening type when the confining pressure is above $200 \mathrm{kPa}$, the failure mode of diatomite soil changes from brittle failure mode to plastic failure mode. When the water content of the soil sample is low, strain hardening will occur while the soil sample is damaged. The stress-strain curve of soil can be preliminarily fitted by hyperbolic equation [35]. The abscissa and ordinate of the curve equation are the principal strain $\varepsilon$ in the shearing process of diatomite soil and the ratio $\varepsilon /\left(\sigma_{1}-\sigma_{3}\right)$ of the difference between the principal strain and the principal stress, respectively. The hyperbolic equation is as follows (1). From the hyperbolic equation, the equation on both sides of the equal sign can be obtained by mathematical operation, as follows (2):

$$
\begin{gathered}
\sigma_{1}-\sigma_{3}=\frac{\varepsilon}{a+b \varepsilon} \\
\frac{\varepsilon}{\sigma_{1}-\sigma_{3}}=a+b \varepsilon
\end{gathered}
$$

In the formula:

$a$-Reciprocal of initial tangent modulus;

$b$-Reciprocal of limit deviation stress.

According to the shear curves of diatomite soil under the confining pressures of $200 \mathrm{kPa}, 300 \mathrm{kPa}$, and $400 \mathrm{kPa}$ with dry densities of $1.40 \mathrm{~g} / \mathrm{cm}^{3}$ and $1.50 \mathrm{~g} / \mathrm{cm}^{3}$, the $\varepsilon$ and $\varepsilon /\left(\sigma_{1}-\sigma_{3}\right)$ values of the samples are fitted in a straight line. The resulting curve under the representative confining pressure of $200 \mathrm{kPa}$ is shown in Figure 7.

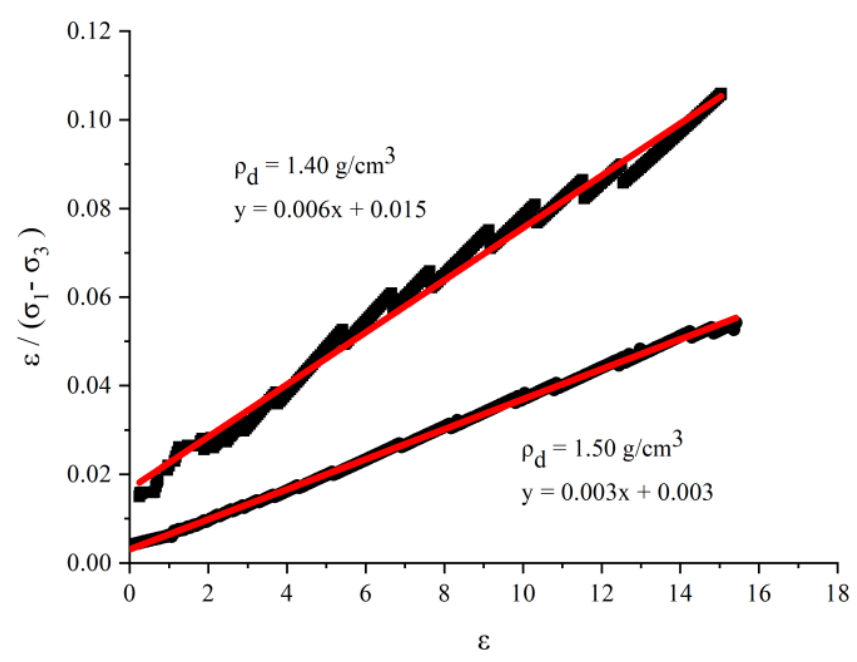

Figure 7. Fitting curve of diatomite soil with different dry density under $200 \mathrm{kPa}$ confining pressure.

It can be seen that the relationship between $\varepsilon$ and $\varepsilon /\left(\sigma_{1}-\sigma_{3}\right)$ of the shear results of diatomite soil under different confining pressures shows a high linear correlation in the equation, and the linear fitting effect is good. The results show that when the dry density of diatomite soil is $1.40 \mathrm{~g} / \mathrm{cm}^{3}$ and $1.50 \mathrm{~g} / \mathrm{cm}^{3}$ under a high confining pressure condition, the stress-strain curve of diatomite soil conforms to the weak hardening relationship of the soil sample, and the overall curve trend is similar to a hyperbola.

The values of $a$ and $b$ at each confining pressure obtained by fitting the linear equations of $\varepsilon$ and $\varepsilon /\left(\sigma_{1}-\sigma_{3}\right)$ is shown in Table 3. It can be seen that the inverse of the initial tangent modulus $a$ and the inverse of the limit deviation stress $b$ for the equation will change, the trend is that the value of $a$ increases gradually and the value of $b$ decreases gradually with the increase in confining pressures. 
Table 3. Fitting line parameters.

\begin{tabular}{cccc}
\hline$\rho_{d} /\left(\mathbf{g} / \mathbf{c m}^{3}\right)$ & Confining Pressure $/ \mathbf{k P a}$ & $\boldsymbol{a}\left(\mathbf{1 0}^{-\mathbf{3}}\right)$ & $\boldsymbol{b} \mathbf{( \mathbf { 1 0 } ^ { - \mathbf { 4 } } )}$ \\
\hline \multirow{3}{*}{1.40} & 200 & 14.8 & 61 \\
& 300 & 21.0 & 51 \\
\multirow{3}{*}{1.50} & 400 & 23.5 & 37 \\
& 200 & 3.1 & 34 \\
& 300 & 7 & 30 \\
& 400 & 12 & 20 \\
\hline
\end{tabular}

$a=$ reciprocal of initial tangent modulus; $b=$ reciprocal of limit deviation stress.

\section{Conclusions}

The physical properties, mechanical properties, and microstructure of diatomite soil in Zhejiang Province are studied through a series of geotechnical engineering tests in this paper. The mechanism of the deformation and mechanical properties of diatomite soil is analyzed from the macro and micro perspectives. The following conclusions are obtained:

(1) The diatomite soil has special properties different from general soil, including small particle size, low specific gravity value, high liquid-plastic limit, and high compressibility. The strength indexes $c$ and $\varphi$ of diatomite soil will decrease with an increase in water content because diatomite soil is rich in aluminosilicate and contains more kaolinite, mica, and other minerals in mineral composition, which will show strong water absorption and certain volume expansion. Furthermore, the water molecules affect the overlapping cell structure composed of silicon, aluminum, and oxygen. The strength of diatomite soil is greatly affected by water, which has a tremendously adverse effect on the stress and deformation of diatomite soil.

(2) From the SEM analysis, it is found that the unique microstructure of diatomite soil increases the porosity of diatomite soil. When the diatomite soil is relatively dry and the pore is large, the inter layer structural force is mainly provided by the contact of particles, and the contact area is large- the soil structure is relatively stable. When the pores in the soil decrease and are filled by water, the soil particles adhere to each other under the suction. The XRD results show that there are many chemical elements in diatomite soil, including $\mathrm{Si}, \mathrm{K}, \mathrm{Al}, \mathrm{H}, \mathrm{O}$, etc. These elements exist in the form of oxides in diatomite soil. This kind of diatomite soil has higher aluminum content. Aluminum is usually combined with other elements such as silicon and oxygen to form a variety of oxides and minerals.

(3) In the triaxial test, when the dry density of diatomite soil increases from $1.30 \mathrm{~g} / \mathrm{cm}^{3}$ to $1.50 \mathrm{~g} / \mathrm{cm}^{3}$, the effective internal friction angle of diatomite soil increased from $5.6^{\circ}$ to $14.5^{\circ}$, and the effective cohesion increased from $30.9 \mathrm{kPa}$ to $49.6 \mathrm{kPa}$. The stress-strain curve of diatomite soil changed from a weak softening type to a weak hardening type when the confining pressure was above $200 \mathrm{kPa}$. From the stress-strain curve, the linear equation curve of $\varepsilon$ and $\varepsilon /\left(\sigma_{1}-\sigma_{3}\right)$ can be fitted, and the fitting effect is good.

Author Contributions: Methodology, L.G.; validation, Y.L.; data curation, Y.L.; writing-original draft preparation, L.G., Y.L. and O.A.; writing-review and editing, L.G., Y.K. and M.G.; supervision, Y.K. and M.G.; project administration, L.G.; funding acquisition. All authors have read and agreed to the published version of the manuscript.

Funding: Financial support comes from the National Natural Science Foundation of China (Grant No. 52027812), the Fundamental Research Funds for the Central Universities of Hohai University (No. B210202047, B210204020), Shaanxi Key RESEARCH and development Program (2021SF-465) are gratefully appreciated.

Institutional Review Board Statement: Not applicable.

Informed Consent Statement: Not applicable.

Data Availability Statement: Not applicable. 
Conflicts of Interest: The authors declare no conflict of interest.

\section{References}

1. Han, X.Q. Research on the current situation and Countermeasures of diatomite resources development at home and abroad. China Non-Met. Min. Ind. Her. 2001, 2, 3-5.

2. Xiao, L.G.; Zhao, Z.; Yu, W.Z. Development status and Prospect of diatomite at home and abroad. J. Jilin Inst. Constr. Eng. 2010, $27,26-30$.

3. Zhang, Q.; Zhou, X.D. Microstructure and application of diatomite. China Build. Sanit. Ceram. 2005, 12, $116-117$.

4. Sun, Y.L.; Wang, R.; Liu, X.; Dai, E.Q.; Li, B.; Fang, S.; Li, D.Y. Synthesis and Performances of Phase Change Microcapsules with a Polymer/Diatomite Hybrid Shell for Thermal Energy Storage. Polymer 2018, 10, 601. [CrossRef] [PubMed]

5. Chen, J.; Feng, Z.L.; Sheng, Y.; Liu, L.; Li, J. Long-Term Use of Diatomite Slope Embankments in Warm Permafrost Regions. J. Cold Reg. Eng. 2017, 31, 04017003. [CrossRef]

6. Sonyok, D.R.; Bandini, P. Oedometric Behavior of Diatomite-Kaolin Mixtures. J. Geotech. Geoenvironmental Eng. 2019, 145, 1790-2022. [CrossRef]

7. Al-Degs, Y.; Khraisheh, M.A.M.; Tutunji, M.F. Sorption of Lead Ions on Diatomite and Manganese Oxides Modified Diatomite. Water Res. 2001, 35, 3724-3728. [CrossRef]

8. Wang, Y.J.; Tang, Y.; Dong, A.G.; Wang, X.D.; Ren, N.; Gao, Z. Zeolitization of diatomite to prepare hierarchical porous zeolite materials through a vapor-phase transport process. J. Mater. Chem. 2002, 12, 1812-1818. [CrossRef]

9. Liu, J.; Zhao, D.F. Research status and development of diatomite. Environ. Sci. Manag. 2009, 34, 104-106+161.

10. Lu, Y.L.; Wang, L.G.; Sun, X.K.; Wang, J. Experimental study of the influence of water and temperature on the mechanical behavior of mudstone and sandstone. Bull. Eng. Geol. Environ. 2017, 76, 645-660. [CrossRef]

11. Xu, S.C.; Lu, H.J.; Liu, J.Z.; Li, J.X. An experimental study on the microstructure and triaxial shear of structured clay in contact with landfill leachate. Bull. Eng. Geol. Environ. 2019, 78, 4611-4622. [CrossRef]

12. Zhao, M.; Chen, L.Y.; Wang, S.Y.; Wu, H.G. Experimental study of the microstructure of loess on its macroscopic geotechnical properties of the Baozhong railway subgrade in Ningxia, China. Bull. Eng. Geol. Environ. 2020, 79, 4829-4840.

13. Sedat, K.; Ali, K.; Ahmet, S.; Alper, B. Polyethylene glycol (PEG)/diatomite composite as a novel form-stable phase change material for thermal energy storage. Sol. Energy Mater. Sol. Cells 2011, 95, 1647-1653.

14. Noémie, V.G.; Frank, J.C.; Matheus, M.; Carlos, P.B.; Thomas, G. Investigation of clay content and sintering temperature on attrition resistance of highly porous diatomite based material. Appl. Clay Sci. 2011, 52, 120-121.

15. Zhao, Q.R.; Li, L.B. Development, application and progress of diatomite. Chem. Miner. Geol. 2005, 2, 96-102.

16. Hong, Z.S. Study on the Microstructure of Strong Structural Diatomite Under Different Stress Levels. In Proceedings of the 9th soil mechanics and geotechnical engineering academic conference of China Civil Engineering Society, Beijing, China, 1-18 September 2003.

17. Ma, Q.Z.; He, Z.M.; Cai, Z.M. Engineering properties of diatomite in Namibia. Water Transp. Eng. 2017, 12, 80-84.

18. Robert, W.D. Engineering Properties of Diatomaceous Fill. J. Geotech. Eng. 1995, 121, 908-910.

19. Tateishi, Y. Geotechnical Properties of Diatom Earth and Stability of Surface Layer for the Cut Slope; Saga University: Saga, Japan, 1997. (In Japanese)

20. Round, F.E.; Crawford, R.M.; Mann, D.G. The Diatoms-Biology and Morphology of the Genera; Cambridge University Press: London, UK, 1990.

21. Hong, Z.S.; Tateishi, Y.; Deng, Y.F. The relationship between stress level and pore space distribution of natural diatomite. Geotech. Mech. 2004, 7, 1023-1026.

22. Hu, S.Y.; Wen, L. Microscopic characteristics of tertiary diatomite in Linqu, Shandong Province. J. Electron Microsc. $2005,4,319$.

23. Ma, Q.Z.; Wei, D.; Peng, S.Z.; Zhou, J.H. Study on the influence of island building effect on the shear strength of diatomite. Harb. Eng. Technol. 2018, 55, 108-111.

24. Zhang, Y.S.; Guo, C.B.; Qu, Y.X.; Zhang, M. Discovery of expansive diatomite in Tengchong, Yunnan Province and its engineering geological significance. J. Eng. Geol. 2012, 20, 266-275.

25. Zhang, Y.S.; Guo, C.B.; Qu, Y.X.; Yao, X. Study on mechanical properties and disaster effects of expansive diatomite. Geotech. Mech. 2013, 34, 23-30+39.

26. Gao, H.X.; Yin, K.L.; Zhou, C.M. Stability analysis and time prediction of diatomite landslide. J. Northwest Univ. 2007, 1, 127-130.

27. Diaz-Rodríguez, J. Abraham. Diatomaceous Soils: Monotonic Behavior. In Deformation Characteristics of Geomaterials; IOS Press: Seoul, Korea, 2011; pp. 865-871.

28. Kuang, Z.H.; Zhou, X.M. Research and analysis of hole forming technology of cast-in-place pile in diatomite geology. Pearl River Water Transp. 2018, 9, 19-21.

29. Fang, Y.Y.; Jiang, J.; Jiang, H.H. Research on The Microstructure and The Mechanical Properties of Shengzhou Diatomite. Low Temp. Archit. Technol. 2019, 41, 75-77+81.

30. Kang, Y.G.; Gao, L.; Luo, Y.; Gao, M.J.; Wang, Q. Field Test of the Proportional Coefficient m of Horizontal Resistance Coefficient of Diatomaite Layer. Sci. Technol. Eng. 2020, 20, 694-700.

31. Kang, Y.G.; Gao, L.; Luo, Y.; Gao, M.J.; Zhang, Z.L. Study on Boring Test of Bridge Cast-in-place Piles in Diatomite Area. J. Disaster Prev. Mitig. Eng. 2021, 41, 335-342. 
32. Luo, Y.; Gao, L.; Gao, M.J.; Kang, Y.G. Quantitative study on microstructure characteristics of white diatomite. J. Eng. Geol. 2021, 1,1-11.

33. China Academy of Building Sciences. Code for Design of Building Foundation, GB50007-2011; China Building Industry Press: Beijing, China, 2011.

34. Nanjing Water Conservancy Research Institute. Standard for Soil Test Method, GB/T50123-2019; China Water Conservancy and Hydropower Press: Beijing, China, 2019.

35. Gao, L.; Hu, G.H.; Chen, Y.H.; Hu, Y.J.; Gong, Y.H. Triaxial test of basalt fiber reinforced clay. J. Geotech. Eng. 2017, $39,198$. 